\title{
THE EFFECT OF PLAYING METHOD TOWARD BASIC SKILLS OF STUDENTS' PLAYING FOOTBALL
}

\author{
${ }^{1}$ Novri Gazali, ${ }^{2}$ Romi Cendra
}

Correspondence: Islamic University of Riau, Pekanbaru, Indonesia

E-mail: novri.gazali@edu.uir.ac.id, romicendra@edu.uir.ac.id

\begin{abstract}
Abstrak
Tujuan penelitian ini adalah mengungkap pengaruh metode bermain terhadap keterampilan dasar bermain sepakbola. Jenis penelitian ini adalah eksperimen semu (quasy eksperimen), populasi penelitian ini adalah siswa putra SMP Negeri 3 Singingi Hilir Kabupaten Kuansing Provinsi Riau yang berjumlah 32 orang, sedangkan sampel dalam penelitian ini adalah 20 orang siswa setelah menggunakan teknik purposive sampling. Instrumen penelitian yang digunakan adalah tes kecakapan David Lee yang merupakan pengembangan dari David Lee yang dibuat oleh Subagyo Irianto, Data dianalisis menggunakan statistik uji normalitas dan uji-t. Hasil analisis data menunjukkan bahwa terdapat pengaruh metode bermain yang signifikan terhadap keterampilan dasar bermain sepakbola siswa SMP Negeri 3 Singingi Hilir Kabupaten Kuansing Provinsi Riau, dari rata-rata 26.20 pada tes awal menjadi 27.84 pada tes akhir, dengan beda mean 1.64 (thitung = 3.17 > ttabel $=1.729)$. Metode bermain memberikan pengaruh yang signifikan terhadap keterampilan dasar bermain sepakbola siswa SMP Negeri 3 Singingi Hilir Kabupaten Kuansing Provinsi Riau.
\end{abstract}

\section{Kata Kunci: Metode Bermain, Keterampilan Dasar, Sepakbola}

\section{Journal Physical Educ Abstract ealth and Recreation}

The research aimed to reveal the effects of playing methods for basic skills in football. The type of this research was quasy experiment. Population in this research was 32 students of SMPN 3 Singingi Hilir Kuansing Regency Riau Province, and the sample in this research after using purposive sampling was 20 students. Research instrument used in this research was football skills test David Lee which was the development from David Lee created by Subagyo Irianto. Data was analyzed by statistics of normality-test and t-test. Data analysis results showed that there was a significant effect in playing method for basic technique skills in football, which was from average 26.20 in pre-test to 27.84 in post-test, mean difference was 1.64 , with thit $=3.17>$ ttab $=1.729$. The method of playing gave a significant influence on the basic skills of playing football of SMP Negeri 3 Singingi Hilir students in Kuansing Regency, Riau Province.

Keywords: Playing Method, Basic Technique Skill, Football

PJKR

http://jurnal.unimed.ac.id/2012/index.php/jpehr 


\section{Introduction}

Sport is a part of human life. Exercising can improve physical fitness or physical condition of a person so that they can do daily activities without experiencing significant fatigue. Through sports activities can form a healthy human body and have a disciplined character and high sportsmanship and ultimately form a quality human being. The development of sports in Indonesia now feels more advanced, this is inseparable from the participation of people who are increasingly aware and understand the importance of the function of the sport itself, in addition to the attention and support of the government also supports the development of sports in Indonesia.

Sport is one of the efforts in improving the quality of human resources that is why there is a need for training and sports development. As stated in UU Number 3 Clause 21 in 2005 concerning the National Sports System, namely:

"The Government and Regional Governments must provide guidance and development of sports in accordance with their authorities and responsibilities, (2) training and development including sports, personnel, organizing, funding, methods, infrastructure and facilities as well as sports awards, (3) training and development of sports are carried out through sports introduction, monitoring, scouting and talent development and achievement improvement and (4) training and development are carried out through family, education and community based channels on the development of sports for everyone that lasts a lifetime ".

Based on the description above, it is clear that sport has very complex goals. One of them is in physical education at school, which is to conduct training in schools in order to produce students who are healthy, fit and also of good quality. Physical education is an integral part of total education that tries to achieve the goal of developing physical, mental, social and emotional fitness for the community by means of physical activity. Physical education and health is part of gverall education, aims to develop aspects of physical fitness, movement skills, critical thinking skills, social skills, reasoning emotional stability, moral actions, aspects of healthy living patterns and the introduction of a clean environment through elected physical activities, health and sports are planned systematically to achieve national education goals.

SMP Negeri 3 Singingi Hilir, is one of the official educational institutions that has a role in fostering and developing physical education and sports students in Kuansing Regency, Riau Province, especially in football. One effort that can be done at SMP Negeri 3 Singingi Hilir is to teach and develop basic skills in students through physical education subjects and extracurricular activities in schools.

The importance of basic mastery of playing football in junior high schools as an illustration of the ability and skills level possessed is to face the Indonesian Education League (LPI) which is usually held every year. In order to master the basic skills of playing football, students must practice correctly and continuously on all the factors that determine or influence the mastery of those basic skills in playing football. 
The achievements of Singingi Hilir State Junior High School 3 obtained through football extracurricular activities two years ago were quite promising, because the Singingi Hilir State Junior High School 3 students won first place in the Indonesian Education League (LPI) in Kuansing District in 2012 and won second place in 2013. However, in 2014 there was a decrease in achievement and did not get any degree, this is because the basic skills of football in the students of SMP Negeri 3 Singingi Hilir are still not good.

This can be seen from the observations of researchers when students did exercises that were still errors in the implementation of basic football techniques. This mistake was like when a student did passing, passed the ball often was not right to the target or to his friend, while controlling or stopping the ball with legs or chest, the controlled ball is always loose and easily taken by the opponent. Likewise when dribbling ball did not look good enough, and when heading the ball the students looked a little stiff and the ball was not right on the forehead, then when shooting or kicking a ball came up with a lot of technical errors, for example when kicking there were still using the tip feet and when kicking the goal often did not lead to the goal.

Of course the lack of basic skills in playing football does not stand alone, this was influenced by a number of factors, either internal or external. Internal factors that influence the physical condition of students greatly affect the basic skills of playing football. Students who have good physical condition are expected to be able to undergo the training program given by the trainer or teacher, the weight or light intensity given will be lived well. Conversely, students who do not have a good physical condition have difficulty in undergoing a series of exercises given by the trainer or teacher, then the motivation of students in undergoing the training process affects the mastery of football playing skills. Those who have good motivation will always try to learn every movement of football techniques. Otherwise, students who have no motivation will be lazy to learn it, they tend to wait for the instructor to instruct them first.

Beside the internal factors above, there were external factors that influenced such as facilities and infrastructure in State Junior High School 3 Singingi Hilir which are inadequate, because the field used for football training was uneven ground, so when students did passing, dribbling, shooting, and controlling the ball was not optimal, the lack of balls used when doing football training, then the other external factor was there were still many physical education teachers in State Junior High School 3 Singingi Hilir who still did not have professional competence, such as not fully mastering physical education learning methods, so in developing learning material tended to focus on game activities based on experience rather than theoretical concepts.

Therefore, it is necessary to determine learning methods that can improve student learning outcomes in the mastery of basic skills playing football. Then in this study the teaching method that will be tried in the learning process of playing football's basic skills is the playing method. 
The method of play is a method applied by a teacher in learning activities that are packaged in the form of play or games. Playing is a physical activity of children which is carried out with a sense of fun, simple and the relationship of play as a vehicle for achievement with pleasure. Zalfendi et al (2010) explained "the method of play is one of the physical learning forms that is given at all levels of education, only the portion and form and the method of play are given, must be adapted to aspects that exist in the curriculum and also the factors of age and physical development". Ismail (2006) stated "the method of playing is an activity carried out with or without using tools that can generate understanding or provide information, give pleasure, or develop imagination".

Budiyono (2009) stated in the implementation of learning applies a technique of playing sports in the form of games. Through games, it is expected to increase students' motivation and interest in learning to be higher, so that optimal learning outcomes will be obtained. Meanwhile according to the Ministry of National Education explained the method of playing aimed to teach the game so that children understand the benefits of certain game techniques by introducing certain game situations to children first.

Based on the definition of playing that has been stated above, the method of playing is a form of learning that applies the technique to a game or learns the techniques of a sport that is packaged in the form of a game. In the implementation of playing methods, students learn the techniques of a sport which is packaged in the form of games. From the games carried out there are those who win and there are those who lose. The playing method given at the time of treatment is the method of playing football, where students play games that lead to the process of playing basic football skills.

Playing method is a form of learning that applies techniques to a game. Do not rule out the possibility of bad or low techniques resulting in less interesting games. For this reason, a teacher must be able to handle it. Lutan et al (2000) stated, when the teacher realizes that the low quality of the game is caused by the low ability of the skill, the teacher has several options as follows: (1) The teacher can continue to play the game for some time so that students catch the general idea of the game they are doing, 2) The teacher can return to the lower stages of learning and let students practice combining skills without pressure to master the strategy, (3) The teacher can change skills at a simpler and more mastered level so students can concentrate on learning to play strategies.

\section{Method}

This study used a quasi-experimental type of research (quasi experiment) with the aim of this study to see the effect of playing methods on the basic skills of playing football. The independent variable in this study was the playing method, while the dependent variable was the basic skill of playing football in students of State Junior High School 3 Singingi Hilir Kuansing Regency, Riau Province. 
Before the treatment was conducted, giving a pre-test (initial test) to the sample first. This pre-test aimed to obtain preliminary data about the basic skills in playing football owned by students. After the pre-test, the samples were treated using the playing method. After the treatment was given as many as 12 times the meeting, the sample was given a post-test (final test) which aimed to obtain the final data about the basic skills of playing football.

The population of this research was all students of State Junior High School 3 Singingi Hilir Kuansing Regency, Riau Province who participated in the football extracurricular activities as many as 32 people. The sample was homogeneous because only men are the objects under study. The sampling technique in this study used purposive sampling with certain considerations. Based on this, the researchers determined the sample in this study were male students of class VII and VIII totaling 20 people. Because of additional study in preparation for the final national examination, grade IX students did not get permission from the principal to be sample

This research instrument used a football skill test, the development of David Lee's proficiency test, which was a development of David Lee made by Subagyo Irianto, this test was hopefully more refined than the original test so that it met the needs / demands of football's progress and development at this time, specifically dealing with state junior high school students 3 Singingi Hilir to be able to evaluate the programs that have been run.

This test was a series of tests so that this test was simpler both in terms of equipment, staff, time and place / area used. The elements assessed / measured are elements of basic football techniques which include dribbling, stopping / controlling under ball, passing / shooting. Irianto (2010) said:

The development test of the "David Lee proficiency test" has been declared valid, reliable, and objective, so that this test can be used as a standard test to measure the level of football playing skills for students of SSB KU 14-15 years. This is evidenced from the results of research showing that concurrent validity of the test results obtained by calculation of 0.484 which means valid and reliability of the test results obtained $\mathrm{rh}=0.942$ greater than $\mathrm{rt}=0.023$ means reliable. The data obtained was processed by "t test". Before the data was processed, an analysis of the requirements test was conducted, namely the normality test using the Liliefors Test with a significance level of $\alpha=0.05$.

\section{Discussion}

The results of measurement data for the initial test data in this group consisting of 20 samples $(n=20)$, obtained the basic skills of playing football with the best time 22.14, lowest time 32.36 , median 27.97 , standard deviation 3.05 , average score (mean) 27.84, while from the results of the final test data analysis after being treated 12 times the best time found was 19.30, the lowest time was 30.56 , the median was 26.24 , the average score was 26.20 , and the standard deviation was 3.05. In order to be clearer about the results of playing method data on the basic skills of playing football of State Junior High School 3 
Singingi Hilir students in Kuansing Regency, Riau Province, it can be seen in Table 1.

Table 1. Frequency Distribution of Initial Test Data Results and Final Test Group Playing Methods

\begin{tabular}{lllllll}
\hline \multirow{2}{*}{ No } & \multirow{2}{*}{ Category } & \multirow{2}{*}{ Interval Class } & \multicolumn{2}{l}{ Initial Test } & \multicolumn{2}{l}{ Final Test } \\
\cline { 3 - 7 } & & Fa & Fr & Fa & Fr \\
\hline 1 & Very good & $>19,46$ & 0 & $0 \%$ & 1 & $5 \%$ \\
\hline 2 & Good & $22,37-19,46$ & 1 & $5 \%$ & 1 & $5 \%$ \\
\hline 3 & Enough & $22,38-24,82$ & 3 & $15 \%$ & 4 & $20 \%$ \\
\hline 4 & Poor & $24,83-27,24$ & 4 & $20 \%$ & 5 & $25 \%$ \\
\hline 5 & Very poor & $<27,24$ & 12 & $60 \%$ & 9 & $45 \%$ \\
\hline \multicolumn{2}{l}{ Total } & & $\mathbf{2 0}$ & $\mathbf{1 0 0 \%}$ & $\mathbf{2 0}$ & $\mathbf{1 0 0 \%}$ \\
\hline
\end{tabular}

Having rank in table 1, it could be seen that the results of the analysis of the initial test data for the group playing method scores on the basic skills of playing football with a very good category which none of the students got it, the good category was only 1 person $(5 \%)$, the category was enough as many as 3 people $(15 \%)$, the category of lacking was 4 people $(20 \%)$, and for the category of very less as many as 12 people (60\%). Furthermore, for the final test results the basic skills score of playing football with a very good category got 1 person (5\%), good category 1 person $(5 \%)$, for the category enough 4 people $(20 \%)$, for the category of less 5 people (25\%), and very few 9 people $(45 \%)$. In this study, the analysis of the test requirements were tested first with the data normality test to find out whether the data from the studied variables were normally distributed or could not be used Lilliefors test with a significance level of $\alpha=0.05$. Lilliefors test hypothesis:

Ho: L observation $<$ Ldata table is normally distributed

Ha: L observation > Ldata table is not normally distributed

Table 2. Playing Method Normality Test

\begin{tabular}{llll}
\hline Data & Lobservation & Ltable & Remarks \\
\hline Playing Method (Initial Test) & 0.0939 & 0.19 & Normal \\
\hline Playing Method (Final Test) & 0.1389 & 0.20 & Normal \\
\hline
\end{tabular}

The statistical test was a t-test which sees the effect of the average count in the same group with a significance level of 0.05 . Preliminary test results of basic skills in playing football of State Junior High School 3 Singingi Hilir students in Kuansing Regency, Riau Province by using the method of playing with a sample of 20 obtained basic skills of playing football with the best time of 22.14 , lowest time of 32.36 , median of 27.97 , standard deviation 3.05 , mean score 27.84 . Furthermore, the final test results of basic skills in playing football using the playing method after being treated 12 times were found to be the best time 19.30, 
the lowest time 30.56, the median 26.24, the average score (mean) 26.20, and the standard deviation 3.05. The results of hypothesis testing are presented in table 3 .

Table 3. Playing Method Hypothesis Test

\begin{tabular}{lllllll}
\hline Playing Method & Mean & SD & T count & T table & $\begin{array}{l}\text { Test } \\
\text { Result }\end{array}$ & Remarks \\
\hline Initial Test & 27.8 & 3.05 & 3.17 & 1.729 & Significant & $\begin{array}{l}\text { Ho rejected and } \\
\text { Ha accepted }\end{array}$ \\
\hline Final test & 26.2 & 3.06 & 3.17 & &
\end{tabular}

From the final test results of the playing method group, after being treated as many as 12 meetings there was a significant increase of 1.64 to the basic skills of playing football. It was known from the initial test and the final test that was from an average score of 27.84 in the pre-test to 26.20 in the post-test. This meant that the hypothesis proposed in this study was accepted empirically correct.

The method of playing gave a significant influence on the basic skills of playing football of State Junior High School 3 Singingi Hilir students in Kuansing Regency, Riau Province. Suyatno (2005) stated that in the playing method if used wisely, can: (1) Getting rid of the seriousness that impedes, (2) eliminating stress in the learning environment, (3) improve the learning process, (4) building selfefficacy, (5) achieving the meaning of learning through experience, (6) focusing students as learning subjects. In the previous theoretical study that playing methods was effective in improving basic skills in playing football, because playing methods made students able to receive material easily, practice and understand what was given by the teacher so that what the teacher wants was achieved.

\section{Conclusion}

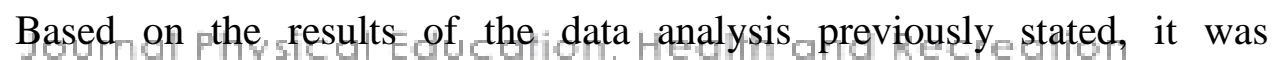
concluded that the playing method has a significant influence on the basic skills of playing football for students of State Junior High School 3 Singingi Hilir Kuansing Regency, Riau Province, from an average of 26.20 on the initial test to 27.84 on the final test, with a mean difference of $1.64(\mathrm{t}=3.17>\mathrm{t}$ table $=1.729)$.

\section{References}

Budiyono, 2009. Metodologi Penelitian Pendidikan. Surakarta: UNS Press Irianto, S, 2010. Pedoman Pelaksanaan Pengembangan Tes Kecakapan David Lee Untuk SSB Umur 14-15 Tahun. Yogyakarta: UNY.

Ismail, Andang, 2006. Education Games "Menjadi Cerdas dan Ceria Dengan Permainan Edukatif”. Yogyakarta: Pilar Media.

Lutan, R, 2000. Supervisi Pendidikan Jasmani: Konsep dan Praktik. Jakarta: Departemen Pendidikan Nasional.

Suyatno, 2005. Permainan Pendukung Pembelajaran Bahasa dan Sastra. Jakarta: Grasindo

PJKR

http://jurnal.unimed.ac.id/2012/index.php/jpehr 
Undang-Undang No 3 tahun 2005, Sistem Keolahragaan Nasional. Jakarta: Biro Humas dan Hukum, Kementerian Negara Pemuda dan Olahraga RI. Zalfendi, Dkk, 2010. Strategi Pembelajaran. Padang: Sukabina Press. 